\title{
Peripheral delta opioid receptors require priming for functional competence in vivo
}

\author{
Matthew P. Rowan ${ }^{1}$, Nikita B. Ruparel ${ }^{2}$, Amol M. Patwardhan ${ }^{3}$, Kelly A. Berg ${ }^{1}$, William P. \\ Clarke $^{1}$, and Kenneth M. Hargreaves ${ }^{1,2,3}$ \\ 1 Department of Pharmacology, University of Texas Health Science Center, San Antonio, TX, 78229-3900 \\ USA \\ 2 Department of Cellular and Structural Biology, University of Texas Health Science Center, San Antonio, \\ TX, 78229-3900 USA \\ 3 Department of Endodontics, University of Texas Health Science Center, San Antonio, TX, 78229-3900 USA
}

\section{Abstract}

\begin{abstract}
Although centrally acting opioid analgesics produce profound antinociception under basal conditions, the antinociceptive properties of peripherally restricted opioid analgesics are generally only detectable after inflammation or injection of inflammatory mediators. Despite considerable research, the cellular mechanisms regulating the functional competence of peripheral opioid receptor systems for inhibition of nociception remain unclear. Recent work has demonstrated that brief pretreatment (priming) with bradykinin, arachidonic acid, protease-activated receptor- 2 agonists, or direct activators of protein kinase $\mathrm{C}(\mathrm{PKC})$ are capable of inducing the functional competence of the opioid receptor system in cultures of primary sensory neurons in vitro. Here we report that the peripheral delta opioid receptor system also requires PKC-dependent priming to inhibit prostaglandin $\mathrm{E}_{2}\left(\mathrm{PGE}_{2}\right)$-induced thermal allodynia in the rat. Peripheral hindpaw injection of [D-Pen $\left.{ }^{2,5}\right]-$ enkephalin (DPDPE), a selective delta opioid receptor agonist, did not alter $\mathrm{PGE}_{2}$-induced thermal allodynia. However, following priming (15 min) with bradykinin or arachidonic acid, DPDPE produced a significant reduction in allodynia that was antagonist reversible, peripherally restricted, and exhibited a typical dose-response relationship. Furthermore, the bradykinin priming effect was blocked by the PKC inhibitors, bisindolylmaleimide I and chelerythrine. Collectively, these data support prior in vitro findings that, although present on primary sensory neurons, peripheral opioid receptor systems are functionally inactive under basal conditions and require activation of a PKCand arachidonic acid-dependent signaling pathway to develop functional competence in vivo.
\end{abstract}

\section{Keywords}

DPDPE; hindpaw; prostaglandin; bradykinin; allodynia

\footnotetext{
Corresponding Author: Dr. Kenneth M. Hargreaves, Department of Endodontics - MC 7892, University of Texas Health Science Center at San Antonio, 7703 Floyd Curl Drive, San Antonio, TX 78229-3900, Voice: (210) 567-3381, Fax: (210) 567-3389, E-mail: hargreaves@uthscsa.edu.

Publisher's Disclaimer: This is a PDF file of an unedited manuscript that has been accepted for publication. As a service to our customers we are providing this early version of the manuscript. The manuscript will undergo copyediting, typesetting, and review of the resulting proof before it is published in its final citable form. Please note that during the production process errors may be discovered which could affect the content, and all legal disclaimers that apply to the journal pertain.
} 


\section{Introduction}

Centrally acting opioids are highly effective at reducing nociceptive behaviors under either basal conditions or after injury. However, drugs that act in the central nervous system (CNS) often trigger potentially serious adverse side effects and opioids are no exception. In contrast to the dramatic antinociceptive effects of centrally acting opioids, peripherally restricted opioids usually have little-to-no detectable effects on basal nociceptive thresholds (for reviews see Cabot, 2001; Przewlocki and Przewlocka, 2001; Stein et al., 2001). Interestingly, although some variability has been reported (Ibrahim et al., 2005), peripherally restricted opioids can have profound efficacy for inhibiting hyperalgesia/allodynia in inflamed tissues (for review, see Stein et al., 2003; 1989; Joris et al., 1987; Ferreira and Nakamura, 1979). Furthermore, peripheral antihyperalgesic/antiallodynic effects of opioids have been reported in models of inflammation (eg., carrageenan, complete Freund's adjuvant, formalin), nerve injury (e.g., chronic constriction injury) and tissue sensitization (e.g., local injection of prostaglandin $\mathrm{E}_{2}$, bradykinin or capsaicin) (Ko et al., 2000; Catheline et al., 1996; Keita et al., 1995; Hong and Abbott, 1995; Levine and Taiwo, 1989; Joris et al., 1987; Ferreira and Nakamura, 1979).

However, whereas numerous animal studies demonstrate nearly $80-100 \%$ efficacy in reversing hyperalgesia/allodynia, this is not the case in clinical trials. Several clinical trials have not detected a significant peripheral component to opioid analgesia, and one systematic review of the clinical literature estimated that the overall efficacy of peripheral opioid analgesia is "mild" for reducing clinical pain (see Gupta et al., 2001). Thus, there is a large difference in efficacy estimates between animal and clinical studies on peripheral opioids. Consequently a better understanding of the mechanisms mediating the development of inflammation-induced functional competence of the opioid receptor system is required.

Peripherally selective opioids may offer reduced risk of CNS-mediated adverse effects, however, comparatively little is known about the cellular mechanisms mediating the development of functional competence of peripheral opioid receptor systems for inhibiting nociception. Recent work has demonstrated that opioid receptor systems on primary sensory neurons in vitro require a pretreatment, or priming stimulus, such as bradykinin, proteaseactivated receptor agonists or arachidonic acid, to inhibit neuropeptide release and adenylyl cyclase activity (Berg et al., 2007a, 2007b; Patwardhan et al., 2006, 2005). Furthermore, induction of opioid receptor system competence is mediated via a cyclooxygenase-dependent arachidonic acid metabolite that is downstream from PKC. However, it is not known whether the development of opioid receptor system competence in vivo requires activation of these cellular signaling pathways. Accordingly, in the present study, we evaluated whether bradykinin and arachidonic acid are effective for priming opioid receptor systems using an in vivo model of thermal allodynia, and further, whether this effect is mediated by activation of PKC signaling pathways.

\section{Materials and Methods}

\subsection{Animals}

Experiments were performed on male Sprague-Dawley rats (175-200g; Charles River, Wilmington, MA). A $12 \mathrm{hr}$ light/dark cycle was used with all testing occurring in the light phase. Animals were housed for 1 week before the experiment with food and water available ad libitum. The animal study protocol was approved by the Institutional Animal Care and Use Committee of the University of Texas Health Science Center at San Antonio and conformed to the International Association for the Study of Pain and US federal guidelines. 


\subsection{Materials}

Prostaglandin $\mathrm{E}_{2}\left(\mathrm{PGE}_{2}\right)$ and arachidonic acid were purchased from Cayman Chemicals (Ann Arbor, MI). Bisindolylmaleimide I (BIS) was purchased from Calbiochem (San Diego, CA). Bradykinin acetate, [D-Pen ${ }^{2,5}$ ]-enkephalin (DPDPE), [D-Ala ${ }^{2}, \mathrm{~N}-\mathrm{Me}-\mathrm{Phe}^{4}, \mathrm{Gly}^{5}$-ol]enkephalin (DAMGO), D-Phe-Cys-Tyr-D-Trp-Orn-Thr-Pen-Thr-NH $\mathrm{N}_{2}$ (CTOP), naltrindole hydrochloride, and chelerythrine chloride were purchased from Sigma-Aldrich (St. Louis, MO). Stock solutions were prepared in ethanol ( $\mathrm{PGE}_{2}$ and arachidonic acid), dimethylsulfoxide (BIS), sterile water (DAMGO, CTOP, DPDPE, naltrindole, and chelerythrine), or saline (bradykinin). All stock solutions were diluted in saline prior to injection (BIS was diluted in saline containing 5\% Tween). Drugs were administered via intraplantar (i.pl.) injection at a final volume of $50 \mu \mathrm{l}$ (BIS injections were $100 \mu \mathrm{l})$.

\subsection{Behavioral Testing}

Paw withdrawal latency (PWL) to a thermal stimulus was measured with a plantar test apparatus (Hargreaves et al., 1988). Briefly, rats were placed in plastic boxes with a glass floor. After a 30 min habituation period, the plantar surface of the hindpaw was exposed to a beam of radiant heat through the glass floor, causing a gradual increase in the temperature of the hindpaw of the animal (Dirig et al., 1997). The PWL was automatically determined by a photoelectric cell. The rate of increase in temperature of the glass floor was adjusted so that baseline PWL values were close to $10 \mathrm{~s}$; cut-off time was $20 \mathrm{~s}$. Measurements were taken in duplicate at least $30 \mathrm{~s}$ apart and the average was used for statistical analysis. Observers were blinded to the treatment allocation.

\subsection{Time Course of Effects}

To evaluate the magnitude and duration of thermal allodynia to $\mathrm{PGE}_{2}$ and bradykinin, animals were injected with vehicle, bradykinin $(25 \mu \mathrm{g})$, or $\mathrm{PGE}_{2}(0.3 \mu \mathrm{g})$ and PWLs were measured every $5 \mathrm{~min}$ for $20 \mathrm{~min}$.

\subsection{Priming Requirement}

To determine if priming is required for functional competence of the peripheral delta opioid receptor system, animals were pretreated with vehicle, bradykinin $(25 \mu \mathrm{g})$, or arachidonic acid $(35 \mu \mathrm{g}) 15 \mathrm{~min}$ prior to co-injection of $\mathrm{PGE}_{2}(0.3 \mu \mathrm{g})$ and either vehicle or DPDPE $(20 \mu \mathrm{g})$. PWLs were measured 5 and 10 min after pretreatment, and every 5 min for 20 min after coinjection. DPDPE was also evaluated with and without bradykinin priming $(25 \mu \mathrm{g})$ at $0.2,2$ and $20 \mu \mathrm{g}$ to assess a dose-response relationship for DPDPE.

\subsection{Peripherally Restricted}

To verify that the effect of DPDPE is mediated in the periphery, animals were pretreated with bradykinin $(25 \mu \mathrm{g}) 15 \mathrm{~min}$ prior to co-injection of $\mathrm{PGE}_{2}(0.3 \mu \mathrm{g})$ and either vehicle or DPDPE $(20 \mu \mathrm{g})$ in the ipsilateral hindpaw and either vehicle or DPDPE $(20 \mu \mathrm{g})$ in the contralateral hindpaw. PWLs were measured on the ipsilateral hindpaw 5 and 10 min after pretreatment, and every 5 min for 20 min after co-injection.

\subsection{Pharmacology}

To determine whether the effects of DPDPE were mediated via delta opioid receptors, animals were pretreated with bradykinin $(25 \mu \mathrm{g})$ and the selective delta opioid receptor antagonist naltrindole $(40 \mu \mathrm{g})$ or bradykinin $(25 \mu \mathrm{g})$ alone $15 \mathrm{~min}$ prior to co-injection of $\mathrm{PGE}_{2}(0.3 \mu \mathrm{g})$ and either vehicle or DPDPE $(20 \mu \mathrm{g})$. PWLs were measured 5 and $10 \mathrm{~min}$ after pretreatment, and every $5 \mathrm{~min}$ for $20 \mathrm{~min}$ after co-injection. In a separate experiment, animals were pretreated with bradykinin $(25 \mu \mathrm{g})$ and the selective mu opioid receptor antagonist CTOP $(10 \mu \mathrm{g})$ or 
bradykinin $(25 \mu \mathrm{g})$ alone 15 min prior to co-injection of $\mathrm{PGE}_{2}(0.3 \mu \mathrm{g})$ and either vehicle, DPDPE $(20 \mu \mathrm{g})$, or the mu opioid receptor agonist DAMGO $(8 \mu \mathrm{g})$. PWLs were again measured 5 and $10 \mathrm{~min}$ after pretreatment, and every $5 \mathrm{~min}$ for $20 \mathrm{~min}$ after co-injection.

To determine whether the priming effect of bradykinin on the peripheral delta opioid receptor system was PKC-dependent, animals were pretreated with the PKC inhibitors chelerythrine (5 $\mu \mathrm{g})$ or BIS $(25 \mu \mathrm{g}) 30 \mathrm{~min}$ prior to priming with vehicle or bradykinin $(25 \mu \mathrm{g})$. Animals were co-injected with $\mathrm{PGE}_{2}(0.3 \mu \mathrm{g})$ and either vehicle or DPDPE $(20 \mu \mathrm{g}) 15$ min post-priming as before. PWLs were measured 5 and 10 min after both PKC-inhibitor injection and priming pretreatments, and every 5 min for 20 min after co-injection.

\subsection{Statistical Analysis}

Results are expressed as mean \pm S.E.M. of 5-9 animals per group and reflect changes from pre-injection baseline PWLs. Statistical significance was determined by one- or two-way ANOVA, where appropriate, with Bonferroni. $P<0.05$ was considered statistically significant.

\section{Results}

Both $\mathrm{PGE}_{2}(0.3 \mu \mathrm{g})$ and bradykinin (25 $\left.\mu \mathrm{g}\right)$ produced significant thermal allodynia (Fig. 1). The peak magnitude of $\mathrm{PGE}_{2}$-induced thermal allodynia was significantly smaller $(\mathrm{P}<0.01)$ than bradykinin-induced thermal allodynia. The bradykinin effect was transient, returning to baseline by $15 \mathrm{~min}$ after injection. The thermal allodynia produced by $\mathrm{PGE}_{2}$ was sustained for the full 20 minutes of the experiment $(\mathrm{P}<0.001)$.

Injection of DPDPE $(20 \mu \mathrm{g})$ into the hindpaw did not alter $\mathrm{PGE}_{2}$-induced thermal allodynia when injected after vehicle pretreatment (Fig. 2). However, 15 min after injection of bradykinin $(25 \mu \mathrm{g})$ into the hindpaw, DPDPE $(20 \mu \mathrm{g})$ completely reversed PGE $_{2}$-induced thermal allodynia, producing withdrawal latencies greater than baseline levels (Fig. 2). Similarly, DPDPE $(20 \mu \mathrm{g})$ also blocked $\mathrm{PGE}_{2}$-induced thermal allodynia following priming with arachidonic acid ( $35 \mu \mathrm{g}$ ), which did not affect the response to $\mathrm{PGE}_{2}$ alone (Fig. 2). Fig. 3 shows the dose-response relationship for DPDPE in bradykinin-primed animals.

In bradykinin-primed $(25 \mu \mathrm{g})$ animals, neither vehicle injected ipsilaterally nor DPDPE (20 $\mu \mathrm{g}$ ) injected contralaterally altered $\mathrm{PGE}_{2}$-induced thermal allodynia (Fig. 4). However, DPDPE $(20 \mu \mathrm{g})$ injected ipsilaterally completely reversed $\mathrm{PGE}_{2}$-induced thermal allodynia to withdrawal latencies above baseline levels (Fig. 4).

Naltrindole pretreatment $(40 \mu \mathrm{g})$ did not affect $\mathrm{PGE}_{2}$-induced thermal allodynia in bradykininprimed $(25 \mu \mathrm{g})$ animals, but reversed the anti-allodynic effect of DPDPE (20 $\mu \mathrm{g}$; Fig. 5). Chelerythrine and BIS pretreatment also had no effect on $\mathrm{PGE}_{2}$-induced thermal allodynia in the absence of bradykinin priming, but both chelerythrine and BIS reversed the effect seen with DPDPE (20 $\mu \mathrm{g})$ in bradykinin-primed ( $25 \mu \mathrm{g})$ animals (Fig. 5). In bradykinin-primed (25 $\mu \mathrm{g})$ animals, peripheral administration of the mu opioid selective agonist, DAMGO $(8 \mu \mathrm{g})$, also reversed $\mathrm{PGE}_{2}$-induced thermal allodynia. The mu opioid selective antagonist, CTOP (10 $\mu \mathrm{g})$, completely blocked the anti-allodynic effect of DAMGO $(8 \mu \mathrm{g})$ but had no effect on DPDPE (20 $\mu$; Fig. 6).

\section{Discussion}

This study demonstrates that the in vivo peripheral delta opioid receptor system does not function to reduce $\mathrm{PGE}_{2}$-mediated thermal allodynia unless a priming stimulus (such as bradykinin or arachidonic acid) is first applied to the tissue. This finding is also consistent with the in vitro culture models of primary sensory neurons for both mu- (Berg et al., 2007a; 
2007b) and delta-opioid receptors (Patwardhan et al., 2006; 2005) where opioid receptor activation does not inhibit neuropeptide release or adenylyl cyclase activity unless primed with bradykinin, PAR-2 agonists, arachidonic acid or PKC activators. Similarly, the majority of studies (for reviews see Cabot, 2001; Przewlocki and Przewlocka, 2001; Stein et al., 2001), but not all (Ibrahim et al., 2005), indicate peripherally administered opioids have no appreciable antinociceptive effects, but can, under appropriate conditions such as inflammation, exert profound antihyperalgesic/antiallodynic effects.

Following bradykinin priming, the antiallodynic effect of DPDPE did not occur when DPDPE was injected into the paw contralateral to the hindpaw receiving the bradykinin priming and $\mathrm{PGE}_{2}$ injection, indicating that, under these experimental conditions, the effect of DPDPE was localized to the ipsilateral inflamed hindpaw. The DPDPE effect was reversed by the delta opioid receptor antagonist naltrindole and not by the mu opioid receptor antagonist CTOP, suggesting mediation by peripheral delta receptors in the hindpaw. Furthermore, the efficacy of DPDPE was substantial, as $\mathrm{PGE}_{2}$-induced thermal allodynia was blocked completely.

PKC has been demonstrated to be important in the regulation of nociceptor function (Blaukat, 2003; Souza, 2002; Cesare et al., 1999) and activation of PKC signaling pathways is required for priming of the peripheral opioid receptor system in vitro by bradykinin (Patwardhan et al., 2005; Berg et al., 2007a). Our findings here are consistent with these in vitro results since two structurally distinct PKC inhibitors, chelerythrine and BIS, reversed DPDPE-mediated antinociception following bradykinin priming. Since PKC is activated in response to bradykinin receptor stimulation (Leeb-Lundberg et al., 2005), it is likely that BIS and chelerythrine blocked the priming effect of bradykinin.

Recently, it has been shown that the opioid receptor system on peripheral sensory neurons may be functionally primed not only by administration of bradykinin, but also by exogenously applied arachidonic acid, and that arachidonic acid, produced downstream from PKC, mediates the priming effect of bradykinin (Berg et al., 2007a; Patwardhan et al., 2005). Here we also found that arachidonic acid can substitute for bradykinin priming to induce functional competence of the peripheral delta opioid receptor system in vivo. Taken together, these studies suggest that opioid receptor system functional competence in vivo can be produced by activation of Gaq-coupled receptors and is dependent upon activation of PKC and production of arachidonic acid. Further, these data demonstrate strong congruence with those obtained with primary cultures of sensory neurons, suggesting that the cell culture model may be useful in delineating the mechanisms of regulation of opioid receptor system functional competence.

In addition to activation of $\mathrm{Gq} / 11$-mediated signaling pathways, functional competence of opioid receptor systems may be induced by other mechanisms. For example, in trigeminal and nodose neurons pretreated with forskolin, adenosine $\mathrm{A} 1$ and mu opioid receptors are responsive to inhibit CGRP release and voltage-dependent cation channels (Carruthers et al. 2001; Ingram and Williams, 1994). These data suggest that perhaps cAMP produced via activation of adenylyl cyclase may also act as a priming stimulus. Furthermore, following pre-treatment with capsaicin, which activates TRPV1 channels, in dorsal root ganglion neurons or animals in vivo, mu opioid receptors were functional to inhibit TRPV1 currents and thermal allodynia, respectively (Endres-Becker et al., 2007), suggesting that perhaps increases in intracellular calcium as a result of TRPV1 activation (for review see Caterina and Julius, 2001), may also promote competence.

The changes within the opioid receptor system that underlie the enhanced responsiveness following a priming stimulus are not known. Such changes may include increased receptor density on the cell surface, increased affinity of agonist for the receptor or enhanced coupling of receptor to $\mathrm{G}$ proteins. Previous work with primary cultures of rat trigeminal ganglion 
suggests that priming with bradykinin increases the ability of MOR agonists to stimulate GTP $\left[\gamma^{35} \mathrm{~S}\right]$ binding (Berg et al., 2007a), which could result from any of the above mechanisms. Identification of the mechanisms responsible for induction of opioid receptor system competence may allow for new adjuvant treatments for improved pharmacotherapy with peripherally selective opioids.

Understanding the mechanisms underlying development of functional competence of the peripheral delta opioid receptor system by bradykinin- or arachidonic acid-mediated priming may have fundamental significance for treatment of peripheral pain disorders. Peripherally restricted opioid analgesics have the advantage of reduced centrally mediated adverse effects, however, in clinical studies the analgesic efficacy of peripherally applied opioids is variable and some studies have not detected a significant peripheral component to opioid analgesia. A better understanding of the cellular mechanisms by which opioid receptor system functional competence is produced and maintained will aid in the development of improved pharmacotherapy for peripheral pain conditions.

\section{Supplementary Material}

Refer to Web version on PubMed Central for supplementary material.

\section{Acknowledgements}

The authors would like to thank Dharshini Amarneethi for excellent technical assistance. This work was supported by USPHS grant P01DA016719, a Research Support Grant award from the Oral and Maxillofacial Surgery Foundation, the Texas Advanced Research Program under Grant No. 3659-0023, and COSTAR Training Grant NIDCR T32DE14318 (M.P.R.).

\section{References}

Berg KA, Patwardhan AM, Sanchez TA, Silva YM, Hargreaves KM, Clarke WP. Rapid modulation of $\mu$-opioid receptor signaling in primary sensory neurons. J Pharmacol Exp Ther 2007a;321:839-847. [PubMed: 17347322]

Berg KA, Zardeneta G, Hargreaves KM, Clarke WP, Milam SB. Integrins regulate opioid receptor signaling in trigeminal ganglion neurons. Neurosci 2007b;144:889-897.

Blaukat A. Structure and signaling pathways of kinin receptors. Andrologia 2003;35:17-23. [PubMed: 12558525]

Cabot PJ. Immune-derived opioids and peripheral antinociception. Clin Exp Pharmacol Physiol 2001;28:230-232. [PubMed: 11236131]

Carruthers AM, Sellers LA, Jenkins DW, Jarvie EM, Fenuik W, Humphrey PPA. Adenosine A1 receptormediated inhibition of protein kinase A-induced calcitonin gene-related peptide release from rat trigeminal neurons. Mol Pharmacol 2001;59:1533-41. [PubMed: 11353815]

Caterina MJ, Julius D. The vanilloid receptor: a molecular gateway to the pain pathway. Ann Rev Neurosci 2001;24:487-517. [PubMed: 11283319]

Catheline G, Kayser V, Guilbaud G. Further evidence for a peripheral component in the enhanced antinociceptive effect of systemic morphine in mononeuropathic rats: involvement of kappa-, but not delta-opioid receptors. Eur J Pharmacol 1996;315:135-143. [PubMed: 8960876]

Cesare P, Dekker LV, Sardini A, Parker PJ, McNaughton PA. Specific involvement of PKC- $\varepsilon$ in sensitization of the neuronal response to painful heat. Neuron 1999;23:617-624. [PubMed: 10433272]

Dirig DM, Salami A, Rathbun ML, Ozaki GT, Yaksh TL. Characterization of variables defining hindpaw withdrawal latency evoked by radiant thermal stimuli. J Neurosci Meth 1997;76:183-191.

Endres-Becker J, Heppenstall PA, Mousa SA, Labuz D, Oksche A, Schafer M, Stein C, Zollner C. $\mu-$ Opioid receptor activation modulates transient receptor potential vanilloid 1 (TRPV1) currents in sensory neurons in a model of inflammatory pain. Mol Pharmacol 2007;71:12-8. [PubMed: 17005903] 
Ferreira SH, Nakamura M. Prostaglandin hyperalgesia: the peripheral analgesic activity of morphine, enkephalins and opioid antagonists. Prostaglandins 1979;18:191-200. [PubMed: 230543]

Gupta A, Bodin L, Holmstrom B, Berggren L. A systematic review of the peripheral analgesic effects of intraarticular morphine. Anesth Analg 2001;93:761-770. [PubMed: 11524353]

Hargreaves KM, Dubner R, Brown F, Flores C, Joris J. A new and sensitive method for measuring thermal nociception in cutaneous hyperalgesia. Pain 1988;32:77-88. [PubMed: 3340425]

Hong Y, Abbott FV. Peripheral opioid modulation of pain and inflammation in the formalin test. Eur J Pharmacol 1995;277:21-28. [PubMed: 7635169]

Ibrahim MM, Porreca F, Lai J, Albrecht PJ, Rice FL, Khodorova A, Davar G, Makriyannis A, Vanderah TW, Mata HP, Malan TP. CB2 cannabinoid receptor activation produces antinociception by stimulating peripheral release of endogenous opioids. Proc Natl Acad Sci USA 2005;102:3093-3098. [PubMed: 15705714]

Ingram SL, Williams JT. Opioid inhibition of Ih via adenylyl cyclase. Neuron 1994;13:179-86. [PubMed: 7519024]

Joris JL, Dubner R, Hargreaves KM. Opioid analgesia at peripheral sites: a target for opioids released during stress and inflammation? Anesth Analg 1987;66:1277-1281. [PubMed: 2891323]

Keita H, Kayser V, Guilbaud G. Antinociceptive effect of a kappa-opioid receptor agonist that minimally crosses the blood-brain barrier (ICI 204448) in a rat model of mononeuropathy. Eur J Pharmacol 1995;277:275-280. [PubMed: 7493620]

Ko MC, Tuchman JE, Johnson MD, Wiesenauer K, Woods JH. Local administration of mu or kappa opioid agonists attenuates capsaicin-induced thermal hyperalgesia via peripheral opioid receptors in rats. Psychopharmacol 2000;148:180-185.

Leeb-Lundberg LM, Marceau F, Muller-Esterl W, Pettibone DJ, Zuraw BL. International Union of Pharmacology. XLV. Classification of the Kinin Receptor Family: from Molecular Mechanisms to Pathophysiological Consequences. Pharmacol Rev 2005;57:27-77. [PubMed: 15734727]

Levine JD, Taiwo YO. Involvement of the mu-opiate receptor in peripheral analgesia. Neurosci 1989;32:571-575.

Patwardhan AM, Berg KA, Akopian AN, Jeske NA, Gamper N, Clarke WP, Hargreaves KM. Bradykinininduced functional competence and trafficking of the $\delta$-opioid receptor in trigeminal nociceptors. $\mathrm{J}$ Neurosci 2005;25:8825-8832. [PubMed: 16192372]

Patwardhan AM, Diogenes A, Berg KA, Fehrenbacher JC, Clarke WP, Akopian AN, Hargreaves KM. PAR-2 agonists activate trigeminal nociceptors and induce functional competence in the delta opioid receptor. Pain 2006;125:114-124. [PubMed: 16781076]

Przewlocki R, Przewlocka B. Opioids in chronic pain. Eur J Pharmacol 2001;429:79-91. [PubMed: 11698029]

Souza ALS, Moreira FA, Almeida KR, Bertollo CM, Costa KA, Coelho MM. In vivo evidence for a role of protein kinase C in peripheral nociceptive processing. Br J Pharmacol 2002;135:239-247. [PubMed: 11786500]

Stein C, Machelska H, Binder W, Schafer M. Peripheral opioid analgesia. Cuur Opin Pharmacol 2001;1:62-65.

Stein C, Millan MJ, Shippenberg TS, Peter K, Herz A. Peripheral opioid receptors mediating antinociception in inflammation. Evidence for involvement of mu, delta, and kappa receptors. $\mathbf{J}$ Pharmacol Exp Ther 1989;248:1269-1275. [PubMed: 2539460]

Stein C, Shafer M, Machelska H. Attacking pain at its source: new perspectives on opioids. Nat Med 2003;9:1003-1008. [PubMed: 12894165] 


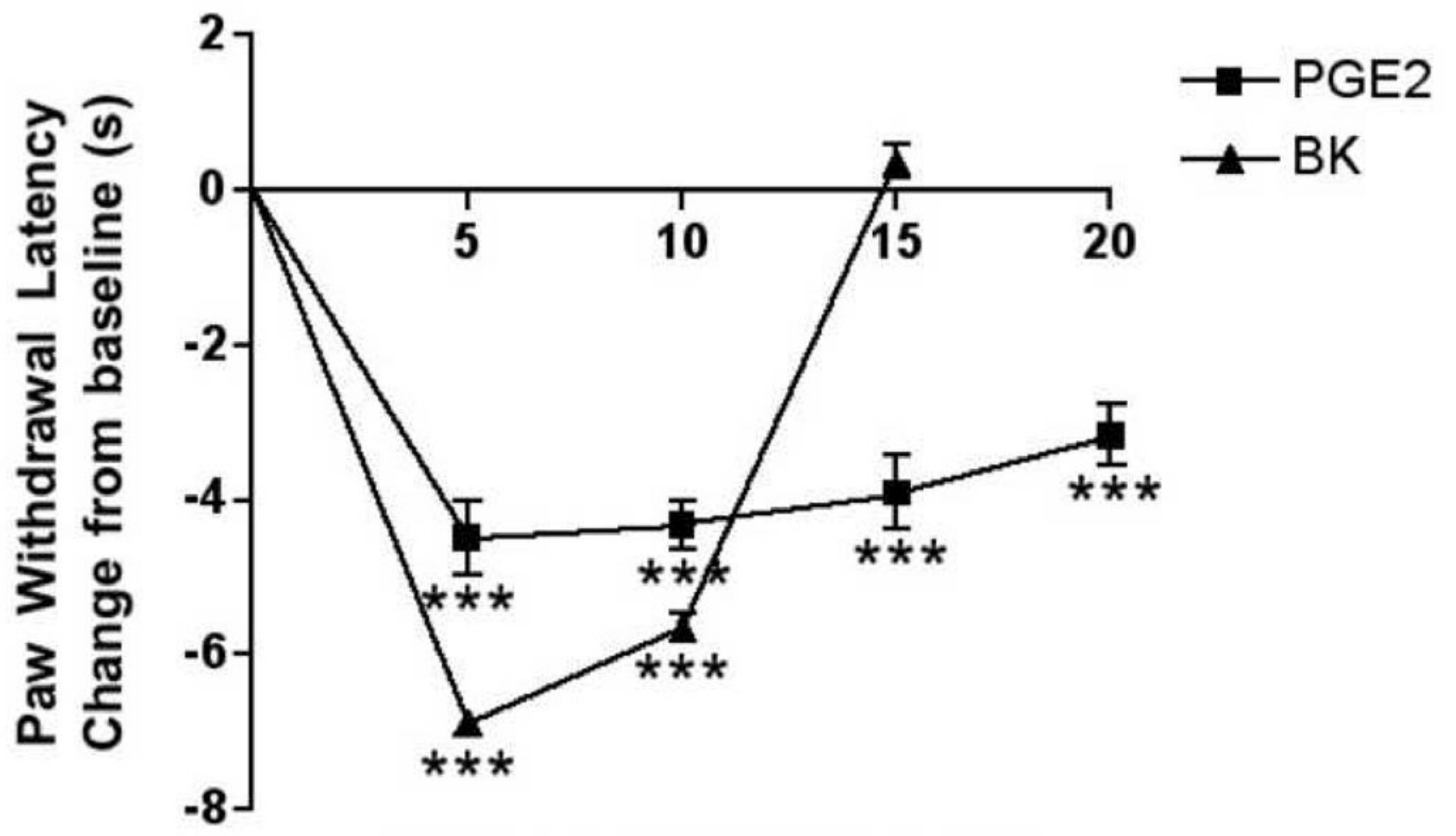

Time after injection ( $\mathrm{min})$

Fig. 1. Time course of bradykinin- and $\mathrm{PGE}_{2}$-induced thermal allodynia Bradykinin (BK; $25 \mu \mathrm{g}$ ) or $\mathrm{PGE}_{2}(0.3 \mu \mathrm{g})$ was injected i.pl. in $50 \mu$ l saline. PWLs were measured at $5 \mathrm{~min}$ intervals for at least $15 \mathrm{~min}$ post-injection. Baseline PWLs were $9.75 \pm 0.40$ s. Data are expressed as mean \pm S.E.M. of 5-9 animals per group (Note: Error bars for some data points are within the size of the symbol). $* * *, P<0.001 \mathrm{vs}$. vehicle treated controls (not shown). All observations were collected by observers blinded to treatment allocation. 


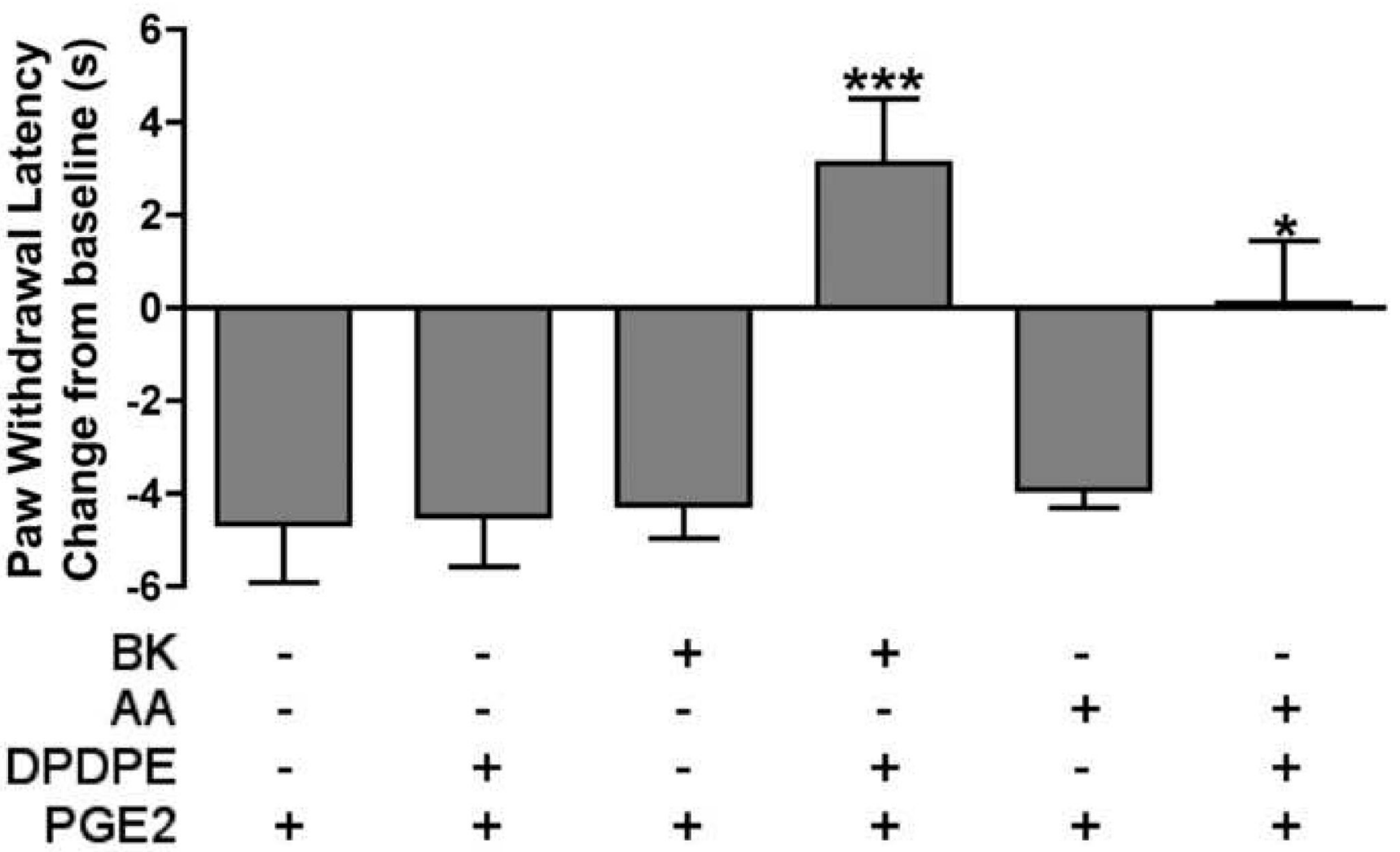

Fig. 2. Functional competence of the peripheral delta opioid receptor system requires priming with bradykinin or arachidonic acid

Separate groups of animals were injected with vehicle, bradykinin (BK; $25 \mu \mathrm{g}$ ), or arachidonic acid (AA; 35 $\mu \mathrm{g}) 15 \mathrm{~min}$ prior to the co-injection of PGE $_{2}(0.3 \mu \mathrm{g})$ and DPDPE $(20 \mu \mathrm{g})$ or vehicle. PWLs were measured at $5 \mathrm{~min}$ intervals for at least $20 \mathrm{~min}$ after the second injection. Baseline PWLs were $8.83 \pm 0.23$ s. Data are expressed as mean \pm S.E.M. PWL measured 10 min after the second injection of 5-9 animals per group. $* * *, *, P<0.001,0.05$ vs. first three groups or vs. AA/Veh/PGE 2 , respectively. 


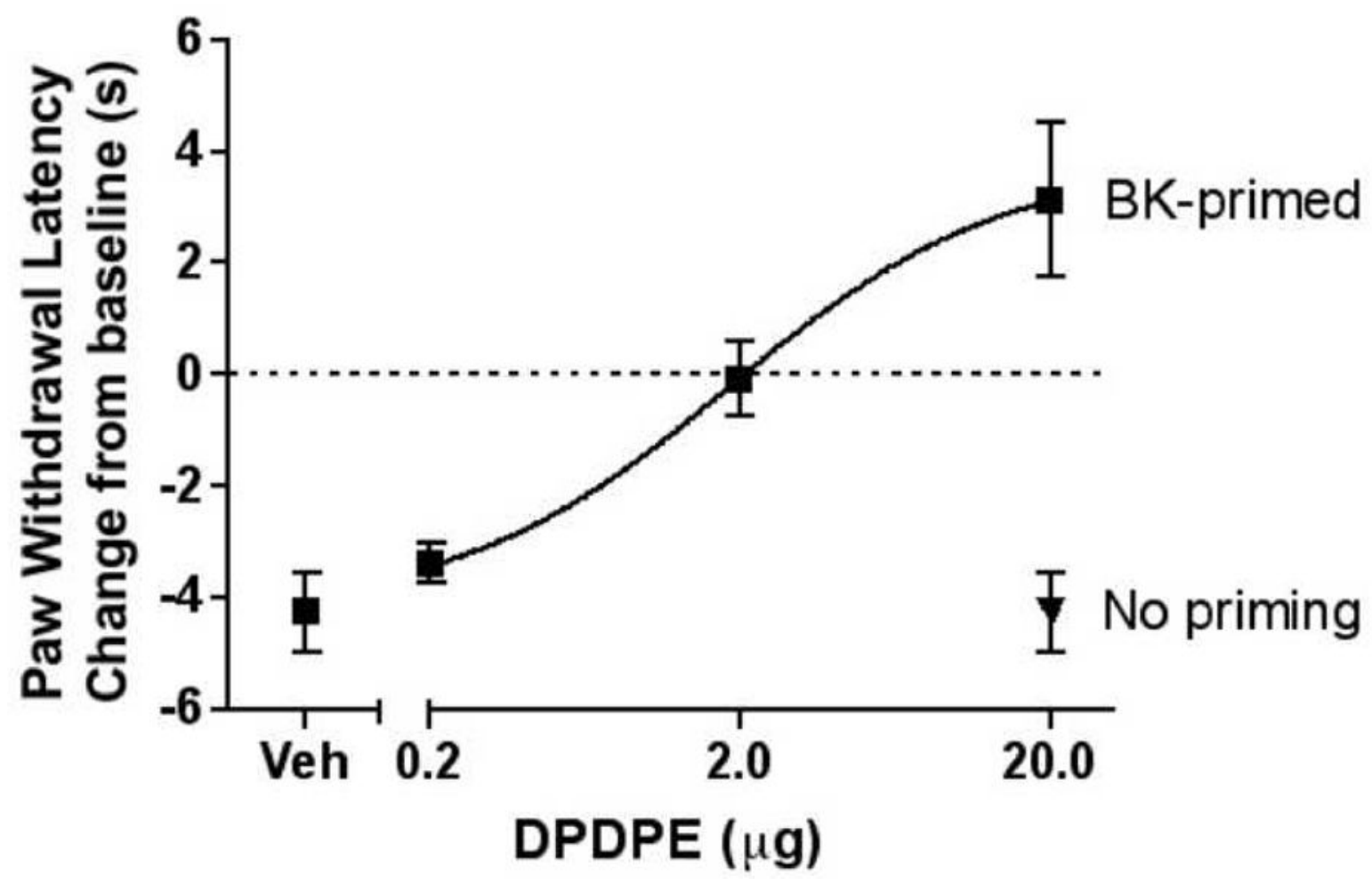

Fig. 3. Dose-response relationship for DPDPE to reduce $\mathrm{PGE}_{2}$-induced thermal allodynia Animals were pretreated with bradykinin $(\mathrm{BK} ; 25 \mu \mathrm{g})$ or vehicle $15 \mathrm{~min}$ prior to the co-injection of $\mathrm{PGE}_{2}(0.3 \mu \mathrm{g})$ and DPDPE $(0.2,2$, or $20 \mu \mathrm{g})$. PWLs were measured at 5 min intervals for at least $20 \mathrm{~min}$ after the last injection. Baseline PWLs were $8.61 \pm 0.27 \mathrm{~s}$. Data are represented as mean \pm S.E.M. PWL measured $10 \mathrm{~min}$ after the last injection of 5-9 animals per group. For comparison, animals receiving bradykinin pretreatment prior to the co-injection of vehicle and $\operatorname{PGE}_{2}(0.3 \mu \mathrm{g})$ are shown on the lower left ("Veh"), and animals not receiving bradykinin pretreatment prior to the co-injection of DPDPE $(20 \mu \mathrm{g})$ and $\mathrm{PGE}_{2}(0.3 \mu \mathrm{g})$ are shown on the lower right ("No priming"). $\mathrm{ED}_{50}=1.84 \mu \mathrm{g}$. 

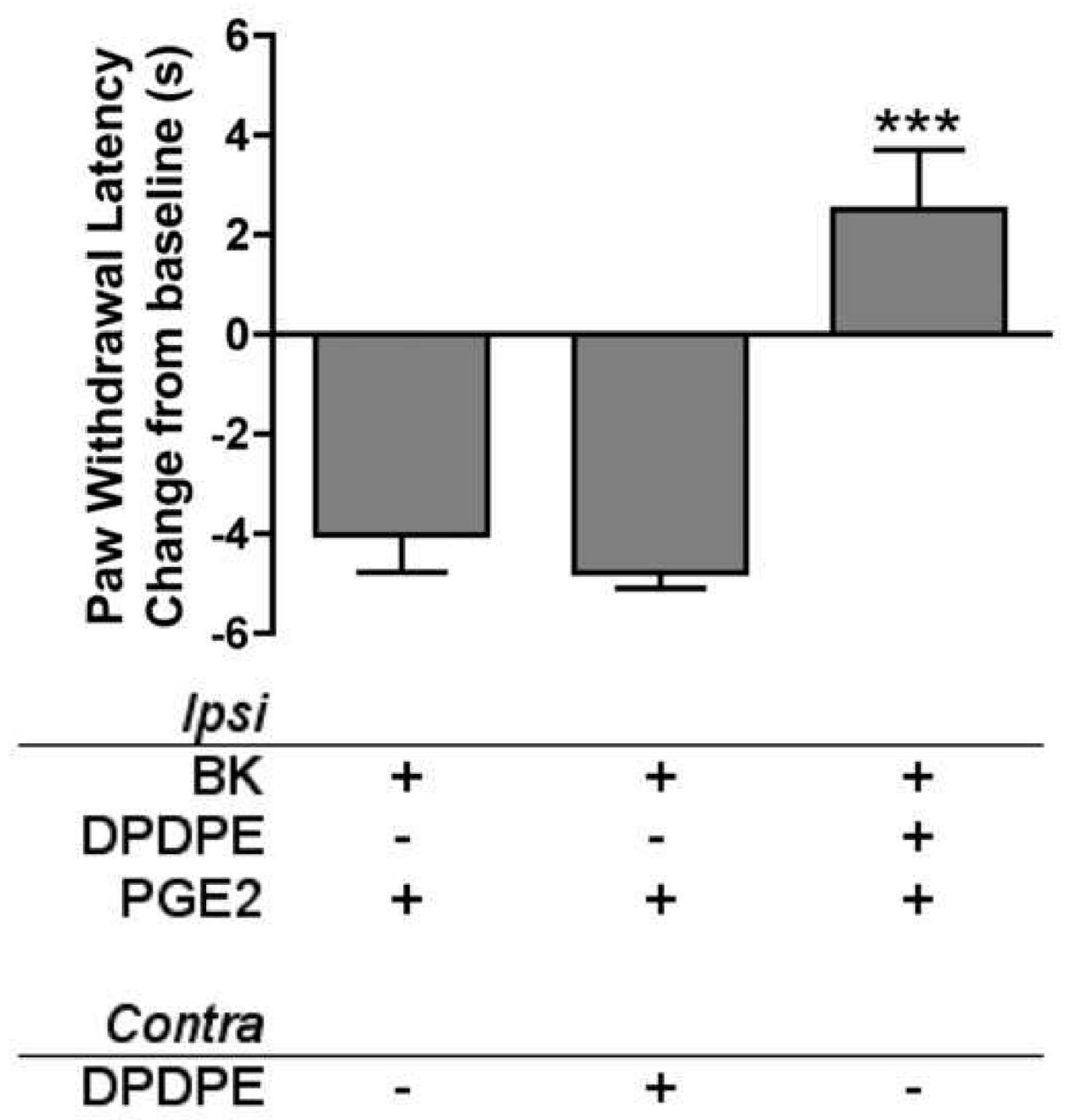

Fig. 4. Antinociception of DPDPE is restricted to the periphery

$15 \mathrm{~min}$ after ipsilateral bradykinin priming (BK; $25 \mu \mathrm{g}$ ), animals received single injections into both the ipsilateral and contralateral hindpaws. All animals received $\mathrm{PGE}_{2}(0.3 \mu \mathrm{g})$ in the ipsilateral hindpaw ("Ipsi"), co-injected with DPDPE $(20 \mu \mathrm{g})$ or vehicle, and either DPDPE $(20 \mu \mathrm{g})$ or vehicle in the contralateral hindpaw ("Contra"). PWLs of the ipsilateral hindpaw were measured at $5 \mathrm{~min}$ intervals for at least $20 \mathrm{~min}$ after the last injection. Baseline PWLs were $10.39 \pm 0.52 \mathrm{~s}$. Data are represented as mean \pm S.E.M. PWL measured $10 \mathrm{~min}$ after the last injection of 5-9 animals per group. ${ }^{* * *}, P<0.001$ vs. both other groups. 


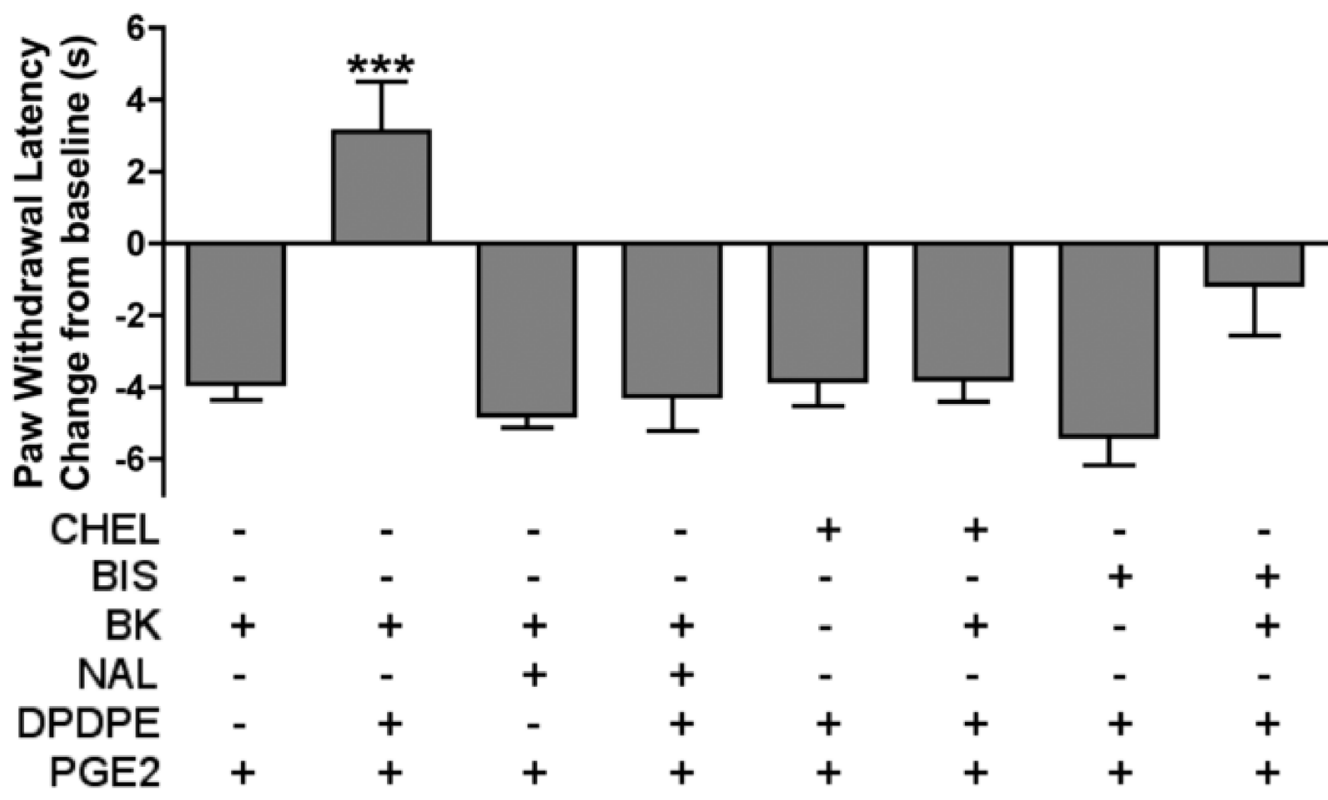

Fig. 5. The anti-allodynic effect of DPDPE is mediated by delta opioid receptors and is PKCdependent

Animals received either bradykinin (BK; $25 \mu \mathrm{g}$ ) or bradykinin with naltrindole (NAL; $40 \mu \mathrm{g}$ ) 15 min prior to the co-injection of PGE $_{2}(0.3 \mu \mathrm{g})$ and DPDPE $(20 \mu \mathrm{g})$ or vehicle (first four bars). In another experiment, separate groups of animals were pretreated with either chelerythrine (CHEL; $5 \mu \mathrm{g})$ or BIS $(25 \mu \mathrm{g} ; 100 \mu \mathrm{l}) 30 \mathrm{~min}$ prior to treatment with either vehicle or bradykinin (BK; $25 \mu \mathrm{g}) ; 15$ min after vehicle or bradykinin, animals were co-injected with $\mathrm{PGE}_{2}(0.3 \mu \mathrm{g})$ and DPDPE $(20 \mu \mathrm{g}$; last four bars). PWLs were measured at 5 min intervals for at least $20 \mathrm{~min}$ after the last injection. Baseline PWLs were $10.50 \pm 0.31 \mathrm{~s}$. Data are represented as mean \pm S.E.M. PWL measured 10 min after the last injection of 5-9 animals per group. ***, $P<0.001$ vs. all other groups. 


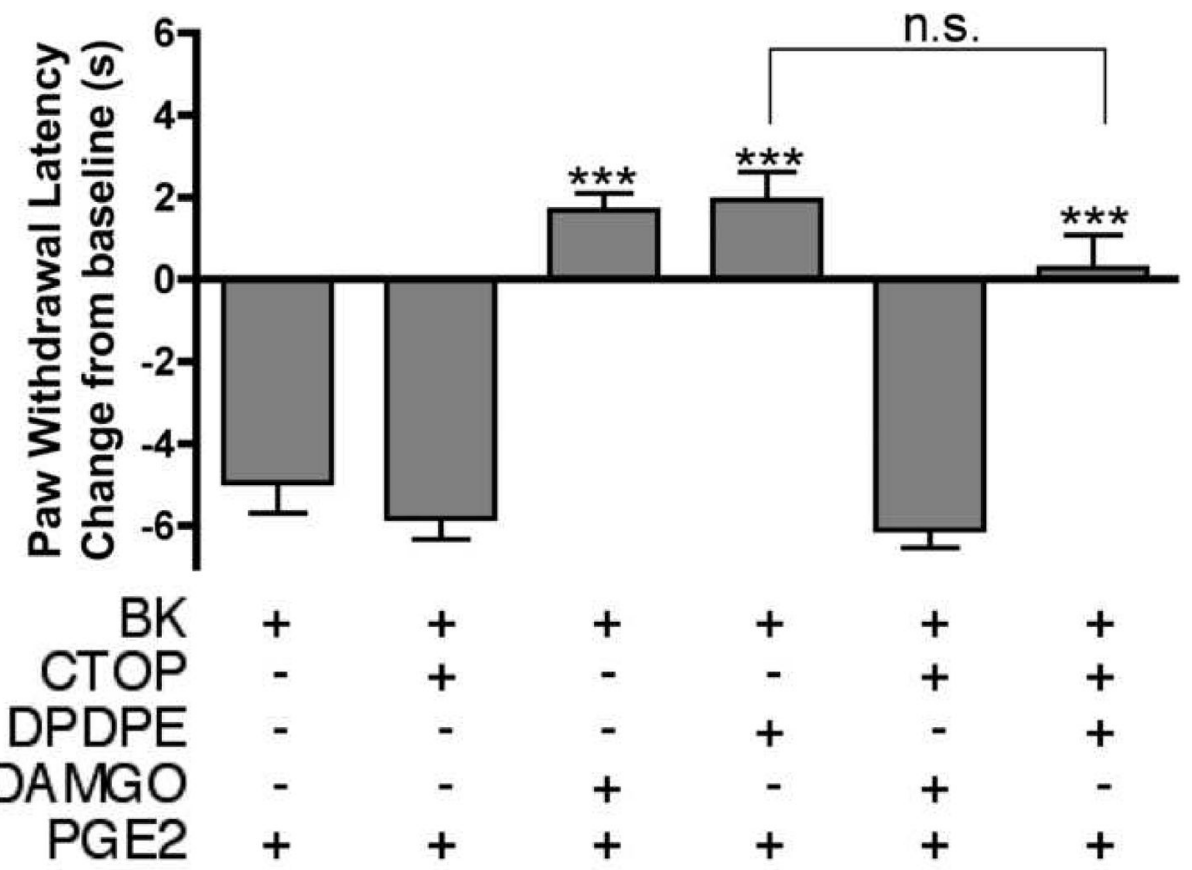

Fig. 6. The anti-allodynic effect of DPDPE is not mediated by mu opioid receptors

Animals received either bradykinin (BK; $25 \mu \mathrm{g}$ ) or bradykinin with CTOP $(10 \mu \mathrm{g}) 15$ min prior to the co-injection of PGE $_{2}(0.3 \mu \mathrm{g})$ and DAMGO $(8 \mu \mathrm{g})$, DPDPE $(20 \mu \mathrm{g})$, or vehicle. PWLs were measured at $5 \mathrm{~min}$ intervals for at least $20 \mathrm{~min}$ after the last injection. Baseline PWLs were $10.27 \pm 0.56 \mathrm{~s}$. Data are represented as mean \pm S.E.M. PWL measured $10 \mathrm{~min}$ after the last injection of 5-9 animals per group. $* * *, P<0.001$ upper three groups vs. lower three groups. n.s., not significant. 